\title{
Effect of an extruded linseed diet on meat quality traits in Nero Lucano pigs
}

\author{
S. Tarricone ${ }^{1}$, M.A. Colonna ${ }^{1 \#}$, F. Giannico ${ }^{1}$, M. Ragni $^{1}$, A. Lestingi ${ }^{2}$ \& A.M. Facciolongo ${ }^{3}$ \\ ${ }^{1}$ Department of Agricultural and Environmental Science, University of Bari Aldo Moro, Via G. Amendola 165/A, 70126, \\ Bari, Italy \\ ${ }^{2}$ Department of Veterinary Medicine, University of Bari Aldo Moro, Strada provinciale Casamassima Km. 3, 70010, \\ Valenzano (BA), Italy \\ ${ }^{3}$ Institute of Biosciences and Bioresources, National Research Council, Via G. Amendola 165/A, 70126, Bari, Italy
}

(Received 14 March 2019; Accepted 15 November 2019; First published online 27 January 2020)
Copyright resides with the authors in terms of the Creative Commons Attribution 4.0 South African Licence. See: http://creativecommons.org/licenses/by/4.0/za
Condition of use: The user may copy, distribute, transmit and adapt the work, but must recognise the authors and the South African Journal of Animal Science.

\begin{abstract}
The study aimed to evaluate the effect of a diet containing extruded linseed (Linum usitatissimum L.) on growth performances, carcass traits and meat quality in Nero Lucano pigs. Sixteen male piglets were weaned at about 50 days of age and divided into two homogeneous groups fed a control diet (C) or a diet containing 3\% extruded linseed (EL). The trial lasted 32 weeks and pigs were slaughtered at 9 months of age. Samples from the Longissimus dorsi $(L d)$ muscle were analysed to assess physical and chemical parameters and intramuscular fatty acid composition. Average daily gain, feed intake and feed conversion ratio were not affected by the diet. Pigs fed the $\mathrm{C}$ diet showed a significantly greater slaughter weight in comparison to the EL group (116.50 vs $108.25 \mathrm{~kg}$ ) Meat $\mathrm{pH}$ and chemical composition were not influenced by the diet. No differences were found for shear force (WBS) in raw meat, while cooked meat of the EL group showed a lower WBS value. The EL diet significantly lowered total SFA and increased total PUFA, of both $n-6$ and $n-3$ series. Among the $n-6$, significant differences between dietary treatments were found for linoleic acid. As for the n-3 series, EL feeding significantly enhanced linolenic acid, EPA, DPA and DHA. Feeding EL also significantly lowered the PUFA/SFA and n-6/n-3 ratios and the Al and TI, with benefits for human health. In conclusion, dietary supplementation with $3 \%$ EL didn't affect growth performance while it improved the fatty acid profile of meat.
\end{abstract}

Keywords: fatty acid profile, feeding, flaxseed, pork

${ }^{\#}$ Corresponding author: mariaantonietta.colonna@uniba.it

\section{Introduction}

There is a growing demand by the modern consumer for meat containing less fat and lower levels of saturated fatty acids, which are considered to increase risk for coronary heart disease (CHD) (Department of Health, 1994). Research in the last twenty years has focused on improving the balance between polyunsaturated fatty acids (PUFA) and saturated fatty acids (SFA) in animal products, since there has been increased recognition of health benefits of PUFA in general, and of n-3 fatty acids in particular, which are essential for humans (Simopolous, 2001). Years of recommendations to reduce red meat consumption have not lowered the incidence of diseases related to dietary fat. Recently, the dogma that meat consumption should be limited in human diets because of its fatty acid composition has become controversial (Vahmani et al., 2015).

In monogastric animals it is possible to enhance the concentration of beneficial $n-3$ fatty acids in the muscle since meat lipids reflect the nature of dietary fat (Kouba \& Mourot, 2011), on the contrary to ruminants in which a well-documented hydrogenating action of rumen microorganisms on dietary fatty acids occurs (Raes et al., 2004). Several lipid sources have been tested for pig feeding with the aim to improve the $\mathrm{n}-6 / \mathrm{n}-3$ ratio of meat that should be $4-5$ or less according to the latest nutritionist recommendations (Duru, 2019). Matthews et al. (2000) reported that feeding whole linseed to pigs increases the $n-3$ fatty acids in various tissues without adverse effects on growth or meat quality. Supplementation with $3 \%$ dietary linseed oil enhanced the daily gain of growing pigs and increased the C18:3n-3 concentration in the adipose tissue (Nguyen et al., 2004). However, PUFA enriched meats are more susceptible to oxidation which may be 
limited by antioxidants. D'Arrigo et al. (2002) found that diet enrichment with linseed oil (3\%) and $\alpha$-tocopherol acetate produced a healthier fat and prevented lipid oxidative deterioration.

Many aspects of meat production quality are related to genotype, sex, and age of the animals and the breeding system that produces them. In Southern Italy, farmers in marginal areas practice environmentally friendly production systems using native genotypes that are well adapted to the environment and able to exploit the feed resources available on the territory (Maiorano et al., 2007; Tarricone et al., 2010; Marsico et al., 2011; Pugliese \& Sirtori, 2012). The Nero Lucano pig is a swine breed that is native to Southern Italy and bred in the interior of the Lucanian region. These pigs are of moderate size, black-cloaked, adaptable to different environments and able to use the poor feed resources present in wild landscapes. This breed has been slowly undergoing genetic erosion over time due to the increasing interest of breeders towards foreign germplasm that is faster growing, more efficient and has better carcass conformation and meat yield. However, meat of this native breed is very much appreciated by the consumer and also for producing salami, since it is considered to be wholesome and flavoursome. However, there are very few studies that characterize the performance and meat quality traits of the Nero Lucano pig (Marsico et al., 2011). Thus, the aim of our study was to investigate the effects of a diet containing extruded linseed (Linum usitatissimum L.) on in vivo growth, carcass traits, meat quality and muscle fatty acid composition in this autochthonous swine breed.

\section{Materials and Methods}

The study was carried out at the farm "Masseria Pian del Camino" located in Albano di Lucania (Latitude $40^{\circ} 36^{\prime} 03.7^{\prime \prime} \mathrm{N}$, Longitude $16^{\circ} 03^{\prime} 00.1^{\prime \prime} \mathrm{E}, 899 \mathrm{~m}$ asl) from October to June 2018. Animals were cared for following the European Union guidelines (Directive 2010/63/EU).

Sixteen male Nero Lucano piglets from two litters were weaned at about 40 days and then divided into two groups of eight animals each homogeneous for age ( $47 \pm 3$ days old) and initial live weight (12.6 \pm 0.2 $\mathrm{kg}$ ). The pigs were housed indoors in a shed; each group was kept in a single pen having a floor covered by straw and a surface of 24 square meters. Each box had front access to an outdoor paddock of 50 square meters. The pigs were assigned to one of the following dietary treatments: a commercial pelleted feed (Control diet, C) and a diet containing 3\% extruded linseed on an as fed basis (EL). The diets were formulated in order to be iso-energetic, iso-proteic, and iso-lipidic (INRA, 1989). Feed and chemical composition and the nutritive value of the feedstuffs are shown in Table 1.

Pigs had free access to water and feed was offered daily each morning at a rate of $110 \%$ of ad libitum intake calculated by weekly weighing-back of refusals. Every day, after the pigs had finished eating, the remaining pellet feeds were weighed to determine the daily feed intake of each group. The individual body weights were recorded at the beginning of the trial (day 0) and every week until slaughtering day (day 224). Feed samples were taken monthly and stored at $-20^{\circ} \mathrm{C}$ until analysis. Average daily gain (ADG), average daily feed intake (ADFI) and feed conversion ratio (FCR, $\mathrm{kg}$ food ingested daily/kg daily body growth) were calculated from these data.

Samples of each diet were ground in a hammer mill with a $1 \mathrm{~mm}$ screen and analysed in triplicate using AOAC (2004) procedures: dry matter (DM) (Method 934.01), ether extract (EE) (Method 920.39), ash (Method 942.05), crude protein (CP) (Method 954.01), and crude fibre (CF) (Method 945.18). The fatty acid profile of each diet was determined using the method described below for meat.

Thirty-two weeks after the beginning of the trial when the pigs were approximately 9 months old they were slaughtered. After an on-farm fasting period of $8 \mathrm{~h}$, the pigs were transported to the abattoir. They were laired for $4 \mathrm{~h}$ with free access to water. Pigs were electrically stunned and following exsanguination, the carcasses were scalded, dehaired and eviscerated. Pigs were weighed at slaughter and hot carcass weight was recorded within 45 minutes after slaughter, in accordance with the Italian ASPA methods (1991).

Within 45 minutes after slaughter the $\mathrm{pH}$ of the Longissimus dorsi $\left(\mathrm{L}\right.$. dorsi) muscle $\left(\mathrm{pH}_{45} \mathrm{~min}\right)$ was measured using a portable instrument (Hanna Instruments $\mathrm{HI} 9025$, Woonsocket, RI) with a penetrating glass electrode (FC 230C, Hanna Instruments) and performing two-point calibration ( $\mathrm{pH} 7.01$ and 4.01). After 24 hours of refrigeration at $0-4^{\circ} \mathrm{C}$ the carcasses were weighed again to calculate the cold yield and the $\mathrm{pH}$ of the $L$. dorsi muscle was again recorded $\left(\mathrm{pH}_{24} \mathrm{~h}\right)$.

The carcasses were divided in half at the midline and the right side was dissected into the following cuts: head, jowl, neck with bone, shoulder, loin, brisket, belly, ham, kidney, flare fat, feet and tail. The ham, loin and shoulder were dissected into their tissue components (lean, separable fat, bone, and rind). 
Table 1 Feed ingredients ( $\mathrm{g} / \mathrm{kg}$ as fed basis), chemical (\% dry matter basis) and FA composition (\% FA methyl esters) of the diets

\begin{tabular}{lrc}
\hline Ingredients (g/kg as-fed basis) & Control feed & Extruded linseed feed \\
\hline Corn & 376.5 & 375.0 \\
Barley & 230.0 & 230.0 \\
Soybean meal $\left(43.4 \%\right.$ CP $^{1}$ ) & 169.0 & 154.0 \\
Wheat flour shorts & 115.0 & 115.0 \\
Wheat middlings & 40.0 & 40.0 \\
Molasses & 30.0 & 30.0 \\
Extruded linseed & 0 & 3.0 \\
Limestone & 14.0 & 14.0 \\
Monocalcium phosphate & 8.0 & 8.0 \\
Sodium chloride & 4.0 & 4.0 \\
Lysine & 1.7 & 1.7 \\
Choline & 0.008 & 0.008 \\
Premix & 1.0 \\
Chemical composition (DM ${ }^{3}$ basis) & 1.0 & 1.0 \\
DE, Mcal/kg & & 3.15 \\
Moisture & 3.15 & 10.40 \\
Crude protein & 10.40 & 15.99 \\
Ether extract & 16.28 & 3.04 \\
Ash & 3.34 & 6.29 \\
Crude fibre & 6.14 & 5.01 \\
Fatty acid composition (\% fatty acid methyl esters) & 4.79 & 14.0 \\
C16:0 & & 3.0 \\
C18:0 & 14.3 & 20.8 \\
C18:1c9 (n-9) & 3.1 & 38.4 \\
C18:2c9,t11 (n-6) & 24.2 & 18.1 \\
C18:3c6,9,12 (n-3) & 30.4 & \\
\hline CP: civdepros & 3.3 & \\
\hline
\end{tabular}

${ }^{1}$ CP: crude protein; ${ }^{2} 1 \mathrm{~kg}$ of Premix contains: vitamin A $6000 \mathrm{IU}$, vitamin D3 $800 \mathrm{IU}$, vitamin E $20 \mathrm{mg}$, niacin $6 \mathrm{mg}$, Ca Dpantothenate $4 \mathrm{mg}$, riboflavin $1.5 \mathrm{mg}$, vitamin K $1 \mathrm{mg}$, vitamin B6 $1 \mathrm{mg}$, vitamin B1 $0.8 \mathrm{mg}$, folic acid $0.25 \mathrm{mg}$, biotin 0.05 $\mathrm{mg}$, vitamin $\mathrm{B} 120.01 \mathrm{mg}$, choline $\mathrm{Cl} 600 \mathrm{mg}, \mathrm{MnO} 25.8 \mathrm{mg}, \mathrm{ZnO} 24.8 \mathrm{mg}, \mathrm{FeSO}_{4} \cdot \mathrm{H}_{2} \mathrm{O} 76 \mathrm{mg}, \mathrm{FeCO}_{3} \cdot \mathrm{H}_{2} \mathrm{O} 20.7 \mathrm{mg}$, CuSO ${ }_{4} \cdot 5 \mathrm{H}_{2} \mathrm{O} 19.65 \mathrm{mg}, \mathrm{Ca}\left(\mathrm{IO}_{3}\right)_{2} 0.62 \mathrm{mg}, \mathrm{Na}_{2} \mathrm{SeO}_{3} 0.18 \mathrm{mg}$, L-lysine monohydrochloride $1.326 \mathrm{mg} ;{ }^{3} \mathrm{DM}$ : dry matter.

The $L$. dorsi samples from the right carcass were used to measure meat colour and tenderness. The colorimetric parameters ( $L^{*}=$ lightness, $a^{*}=$ redness, $b^{*}=$ yellowness) were determined using a Hunter Lab Miniscan $^{\mathrm{TM}}$ XE Spectrophotometer (Model 4500/L, 45/0 LAV, $3.20 \mathrm{~cm}$ diameter aperture, $10^{\circ}$ standard observer, focusing at $25 \mathrm{~mm}$, illuminant D65/10; Hunter Associates Laboratory Inc., Reston, Virginia, USA). Three readings for each sample (measuring approximately $10 \times 15 \mathrm{~cm}$ ) were taken by placing the colorimeter in three different points of the lumbar surface (proximal, central and distal, at about $5 \mathrm{~cm}$ of distance one from another). The instrument was normalized to a standard white tile provided with the instrument before performing analysis $(Y=92.8, x=0.3162$, and $y=0.3322)$ (ASPA, 1996). The reflectance measurements were performed after the samples had oxygenated in air for at least $30 \mathrm{~min}$, at which time the measurements were stable (Šicklep \& Čandek-Potokar, 2007).

Meat tenderness was assessed on raw and cooked $L$. dorsi samples by the Warner Bratzler shear (WBS) force system using an Instron 5544 Universal Testing Machine (Instron Corp., Canton, MA, USA). The samples were cylinders $25.4 \mathrm{~mm}$ in diameter, were assessed in triplicate and sheared perpendicularly to the muscle fibre direction (load cell $50 \mathrm{~kg}$, shearing speed $200 \mathrm{~mm} / \mathrm{min}$ ). Peak force was expressed as $\mathrm{kg} / \mathrm{cm}^{2}$ (ASPA, 1996). 
To determine the cooking loss percentage, homogeneous samples (about $5 \mathrm{~cm}$ thick) were cut from the $L$. dorsi muscle and weighed before and after cooking performed in a ventilated electric oven at $165^{\circ} \mathrm{C}$, until an internal temperature of $75^{\circ} \mathrm{C}$ was reached in the core of the sample (ASPA, 1996), as recorded by a thermocouple (Hanna Instruments, Villafranca, Padovana, Italy).

AOAC (1995) procedures were used to measure moisture, crude fat, protein and ash contents of $L$. dorsi raw samples.

Total lipids were extracted from the homogenized samples $(100 \mathrm{~g})$ using the chloroform/methanol method described by Folch et al. (1957). Fatty acids were methylated using $\mathrm{KOH}$ and methanol (solution $2 \mathrm{~N}$ ) according to Christie (1982) and the fatty acid profile was assessed using a gas chromatograph (Shimadzu GC-17A) with a silicate glass capillary column (70\% Cyanopropyl Polysilphenylenesiloxane BPX 70 of SGE Analytical Science, length $=50 \mathrm{~m}$, internal diameter $=0.22 \mathrm{~mm}$, film thickness $=0.25 \mathrm{~m}$ ). The temperature programme was as follows: $135^{\circ} \mathrm{C}$ for $7 \mathrm{~min}$, followed by increases of $4^{\circ} \mathrm{C}$ per minute up to $210^{\circ} \mathrm{C}$ and held for 2 minutes. The injector and detector temperatures were set up at $245{ }^{\circ} \mathrm{C}$ and $280{ }^{\circ} \mathrm{C}$, respectively. Helium gas was used as carrier with a flow of $1.2 \mathrm{ml} / \mathrm{min}$. Fatty acid were identified using a mixture of standard fatty acids (Restek Corporation, Bellefonte, PA, USA) and were expressed as percentage (wt/wt) of total methylated fatty acids.

The food risk factors of meat were determined by calculating the atherogenic (Al) and thrombogenic (TI) indices (Ulbricht \& Southgate, 1991) as follows:

$$
\begin{gathered}
A l=[(C 12: 0+4 \times C 14: 0+C 16: 0)] \div[\Sigma M U F A+\Sigma n-6+\Sigma n-3] \\
T I=[(C 14: 0+C 16: 0+C 18: 0)] \div[(0.5 \times \Sigma \text { MUFA }+0.5 \times \Sigma n-6+3 \times \Sigma n-3+\Sigma n-3) / \Sigma n-6]
\end{gathered}
$$

where MUFA are monounsaturated fatty acid concentrations.

The data were analysed for variance using the GLM procedure of SAS (SAS Institute Inc., Raleigh, North Carolina, USA). Data were processed by one-way ANOVA with dietary treatment as the main effect. All tables contain Least Squares Means (LSM) and the standard error of the mean (SEM). LSM were compared by the Student's t-test.

\section{Results and Discussion}

Diet had no effect on the average daily gain ( 490 vs $470 \mathrm{~g}, \mathrm{C}$ and EL group, respectively, $P=0.63$ ), feed intake (2050 vs $1970 \mathrm{~g}, C$ and EL group, respectively, $P=0.70$ ) and feed conversion ratio (4.18 vs 4.19, $C$ and EL group, respectively, $P=0.12$ ) in agreement with previous studies which have evaluated the effects of dietary linseed treatments on pig growth and meat quality (Okrouhlá et al., 2013; De Tonnac et al., 2017).

Carcass data are shown in Table 2. Pigs fed the control diet had a greater $(P<0.05)$ slaughter weight in comparison to the extruded linseed group, despite no differences having been observed for feed intake and growth rate. This may be attributable to differences in the amount of gastrointestinal contents. However, this quantity was not assessed. Zhan et al. (2009) reported that stimulatory effects of linseed on growth may not be apparent when the level added is less than $5 \%$. The hot and cold dressing percentages were higher $(P<0.01)$ in pigs fed extruded linseed. Corino et al. (2008) did not find any differences in dressing percentage and carcass traits for pigs fed with a diet containing $5 \%$ extruded linseed and slaughtered at about $110 \mathrm{~kg}$ live weight. De Tonnac et al. (2017) also did not find any differences with regards to growth and carcass traits of pigs fed 3.6\% extruded linseed. However, in lambs (Colonna et al., 2011; Facciolongo et al., 2018) and kids (Rotondi et al., 2018) fed diets containing 3\% extruded linseed significantly greater hot dressing percentages were recorded.

Table 2 Weights and dressing percentages of Nero Lucano pigs fed a control diet or a similar diet that had been supplemented with $3 \%$ extruded linseed

\begin{tabular}{lcccc}
\hline & \multicolumn{2}{c}{ Diets } & \multirow{2}{*}{ SE } & P-value \\
\cline { 2 - 3 } & Control & Extruded linseed & & \\
\hline Slaughter weight $(\mathrm{kg})$ & 116.50 & 108.25 & 10.015 & 0.042 \\
Hot carcass weight $(\mathrm{kg})$ & 96.12 & 95.05 & 1.580 & 0.600 \\
Hot dressing percentage (\%) & 82.51 & 87.80 & 0.558 & 0.0001 \\
Cold dressing percentage (\%) & 78.84 & 83.04 & 0.646 & 0.0001 \\
\hline
\end{tabular}


Table 3 reports the section data from the right half of the carcasses. The extruded linseed dietary treatment produced an increased proportion of feet $(P<0.05)$ and tail $(P<0.01)$, while it reduced the proportion of loin $(P<0.05)$, flare fat $(P<0.01)$, and shoulder $(P<0.01)$. Previously, in pigs fed $5 \%$ linseed and slaughtered at $110 \mathrm{~kg}$, the loin weight/carcass weight ratio was increased Corino et al. (2008), a finding which differs from our results. These differences may be due to the lower percentage of extruded linseed used in the present study or to the genetic difference in the pigs. The carcass data recorded for the control group in this trial confirm the results of Marsico et al. (2011) carried out in Nero Lucano pigs.

Table 3 Carcass weight and percentages of individual cuts from the right half carcass of Nero Lucano pigs

\begin{tabular}{lrrrr}
\hline & & & & \\
Trait & Diets & SE & $P$-value \\
\cline { 2 - 3 } & Control & Extruded linseed & & \\
\hline Half carcass weight $(\mathrm{kg})$ & 46.60 & 45.25 & 4.391 & 0.126 \\
Head & 13.63 & 12.99 & 1.164 & 0.436 \\
Jowl & 2.27 & 2.31 & 0.579 & 0.938 \\
Neck with bone & 8.34 & 8.17 & 0.686 & 0.664 \\
Shoulder & 16.95 & 19.57 & 0.668 & 0.002 \\
Loin & 13.62 & 11.74 & 0.869 & 0.023 \\
Brisket & 1.65 & 1.57 & 0.229 & 0.654 \\
Belly & 10.70 & 11.26 & 1.172 & 0.564 \\
Ham & 28.15 & 28.17 & 1.382 & 0.892 \\
Kidney & 0.39 & 0.39 & 0.057 & 0.904 \\
Flare fat & 2.01 & 0.86 & 0.278 & 0.002 \\
Feet & 1.99 & 2.30 & 0.179 & 0.034 \\
Tail & 0.30 & 0.67 & 0.138 & 0.012 \\
\end{tabular}

Several studies (Maiorano et al., 2007; Juárez et al., 2011; Okrouhlá et al., 2013) summarized the carcass cut-out data as percentages of lean, fatty and other cuts instead of the single meat cuts. In our study, the total lean (sum of ham, loin, neck and shoulder) was 67.06 and $67.65 \%$, respectively, for the C and EL groups, which was greater than comparable estimates of Maiorano et al. (2007) in Casertana pigs and of Corino et al. (2008) in Landrace crossbred pigs slaughtered at a similar age and weight. These results confirm that Nero Lucano is a small size, lean, and rustic pig genotype as reported also by Marsico et al. (2011).

Data from dissection of the ham, loin and shoulder into their tissue components (lean, bone, fat and rind) are shown in Table 4. Although no differences were found between treatments for the weight of the single meat cuts, the control diet resulted in an increased $(P<0.01)$ percentage of lean in the ham and shoulder. Feeding extruded linseed increased the percentages of fat, bone and rind in the ham $(P<0.05)$ and fat and rind in the shoulder $(P<0.01)$. Several authors reported that dietary linseed increased the lean yield of commercially important meat cuts in pigs (Corino et al., 2008; Juárez et al., 2011) and young bulls (Tarricone et al., 2019). However, other investigators (Bee et al., 2008; Bečková \& Václavková, 2010), did not observe any increase in the total lean content; findings which are consistent with our results. 
Table 4 Cut weights and percentages of lean, fat, bone and rind of the ham, loin and shoulder of Nero Lucano pigs

\begin{tabular}{|c|c|c|c|c|}
\hline & \multicolumn{2}{|c|}{ Diets } & \multirow{2}{*}{ SE } & \multirow{2}{*}{$P$-value } \\
\hline & Control & Extruded linseed & & \\
\hline Ham (kg) & 13.09 & 13.47 & 1.864 & 0.786 \\
\hline Lean & 70.85 & 65.88 & 0.976 & 0.001 \\
\hline Bone & 7.30 & 9.44 & 0.914 & 0.016 \\
\hline Fat & 11.19 & 10.55 & 1.015 & 0.405 \\
\hline Rind & 10.66 & 14.14 & 1.805 & 0.035 \\
\hline Loin (kg) & 6.37 & 5.62 & 0.978 & 0.318 \\
\hline Lean & 61.12 & 58.02 & 2.130 & 0.085 \\
\hline Bone & 6.2 & 11.21 & 3.845 & 0.115 \\
\hline Fat & 19.01 & 15.41 & 3.218 & 0.165 \\
\hline Rind & 13.68 & 15.37 & 2.080 & 0.294 \\
\hline Shoulder (kg) & 8.29 & 9.29 & 0.844 & 0.146 \\
\hline Lean & 71.12 & 59.72 & 2.374 & 0.001 \\
\hline Bone & 10.07 & 9.57 & 0.342 & 0.087 \\
\hline Fat & 7.24 & 12.61 & 1.237 & 0.001 \\
\hline Rind & 11.98 & 18.11 & 3.135 & 0.013 \\
\hline
\end{tabular}

Table 5 shows the physical and chemical features of meat from the $L$. dorsi muscle. Meat $\mathrm{pH}$ was not influenced by the diet; and the $\mathrm{pH}$ values of meat recorded at slaughtering and after 24 hours of refrigeration were consistent with those reported in other studies (Maiorano et al., 2007; Corino et al., 2008).

Table 5 Mean ( \pm SE) physical and chemical data of meat from Longissimus dorsi muscle of Nero Lucano pigs

\begin{tabular}{|c|c|c|c|c|}
\hline \multirow{2}{*}{ Trait } & \multicolumn{2}{|c|}{ Diets } & \multirow{2}{*}{ SE } & \multirow{2}{*}{$P$-value } \\
\hline & Control & Extruded linseed & & \\
\hline $\mathrm{pH}_{45 \text { min }}$ & 6.50 & 6.27 & 0.161 & 0.089 \\
\hline $\mathrm{pH}_{24 \mathrm{~h}}$ & 5.53 & 5.62 & 0.248 & 0.617 \\
\hline Lightness $\left(L^{\star}\right)$ & 51.31 & 55.34 & 2.133 & 0.037 \\
\hline Redness $\left(a^{\star}\right)$ & 3.03 & 6.31 & 0.528 & $<0.001$ \\
\hline Yellowness $\left(b^{\star}\right)$ & 10.76 & 13.14 & 0.331 & $<0.001$ \\
\hline WBS $^{1}$ raw meat $\left(\mathrm{kg} / \mathrm{cm}^{2}\right)$ & 3.30 & 2.74 & 0.787 & 0.349 \\
\hline WBS $^{1}$ cooked meat $\left(\mathrm{kg} / \mathrm{cm}^{2}\right)$ & 3.38 & 2.35 & 0.259 & 0.001 \\
\hline Cooking loss (\%) & 26.60 & 32.30 & 2.602 & 0.021 \\
\hline Moisture (\%) & 74.35 & 74.25 & 0.844 & 0.946 \\
\hline Protein (\%) & 22.31 & 21.95 & 0.401 & 0.261 \\
\hline Fat $(\%)$ & 1.80 & 2.30 & 0.603 & 0.290 \\
\hline Ash (\%) & 1.54 & 1.50 & 0.147 & 0.055 \\
\hline
\end{tabular}

${ }^{1}$ WBS: Warner Bratzler Shear Force 
Dietary linseed feeding affected meat colour features since the higher values for lightness $(P<0.05)$, redness $(P<0.01)$ and yellowness $(P<0.01)$ indicated a shift to darker red meat. Bee et al. $(2008)$ and Corino et al. (2008) did not report effects on meat colour, while Juárez et al. (2011) found lower values for L, chroma and hue in pigs fed $5-10 \%$ flaxseed level. The effect of extruded linseed or linseed oil on meat colour features is quite controversial. Barahona et al. (2016) found that the inclusion of dietary whole linseed decreased hue and yellowness whereas it increased redness of beef meat, while Haak et al. (2008) reported no effect of duration or of time of linseed supplementation on pork meat lipid or colour oxidation. Moreover, Kasprzyk et al. (2015) found that the commercial Polish Landrace pig breed had a higher $L^{*}$ value than the autochthonous Pulawska breed which had greater redness. Franci et al. (2005) also reported that meat from Italian local breeds was redder than that of Large White pigs. Wood et al. (2003), furthermore, reported that diets aiming to enrich pig meat in PUFAs may affect colour changes related to the oxidation of red oxymyoglobin to brown metmyoglobin products, leading also to off-odours and off-flavours.

No differences were found between groups as for shear force in raw meat, while cooked meat of the extruded linseed group was more tender $(P<0.01)$ despite a higher cooking loss $(P<0.05)$. The eating quality of pork is a combination of many factors among which tenderness and juiciness are very important. Temperature and duration of cooking have a large effect on the physical properties of cooked meat. Many different experimental methods have been used to cook pork making difficult to directly compare the results. In many studies the final internal temperature is not clearly defined. The mechanical properties of meat have been thoroughly reviewed in many animal species (Bouton et al., 1978; Thompson, 2002; Hoffman et al., 2003; Bekhit et al., 2014; Choe et al., 2016) and are known to be affected by breed, age, sex, rearing system, slaughter weight, muscle, connective tissue protein, collagen content and solubility, fat content and quality, and drip loss. Although meat samples of the EL group showed only a slightly greater fat content, it may be hypothesized that the higher concentration of PUFA fatty acids in their meat and also the quality of intramuscular fat as opposed to its total content, may have affected meat texture. How the extruded linseed diet influences the muscle texture in Nero Lucano pigs still needs to be ascertained since there are no previous references for this native breed.

In this study, the chemical composition of meat was not affected by the diet. Okrouhlá et al. (2013) found similar results.

The fatty acid profile of meat from the L. dorsi is shown in Table 6 . The present study confirms the results published by other authors who found that dietary supplementation with linseed is reflected in the fatty acid profile of pig muscle (Enser et al., 2000; Kouba et al., 2003; Guillevic et al., 2009). In this study, the total amount of SFA was reduced by dietary supplementation with extruded linseed $(P<0.05)$ in agreement with Juárez et al. (2010). Palmitic (C16:0) and stearic (C18:0) acids were both found to be lower in the extruded linseed group when compared to the control pigs, with significant differences $(P<0.01)$ for stearic acid.

Diet did not affect the amount of monounsaturated fatty acids (MUFA) expressed as a proportion of all fatty acid methyl esters. However, feeding extruded linseed did lower the palmitoleic concentration $(P<0.05)$.

Feeding extruded linseed increased $(P<0.01)$ the concentration of total polyunsaturated fatty acids, of both the $\mathrm{n}-6$ series and $\mathrm{n}-3$ series. Among the $\mathrm{n}-6$, differences were found for linoleic acid $(P<0.01)$ as well as for eicosadienoic (C20:2), eicosatrienoic (C20:3), and arachidonic (C20:4) acids $(P<0.05)$. These results are in agreement with Juárez et al. (2010) who found that feeding flax diets for increasing durations prior to slaughter led to linear increases in linoleic acid. We have not performed sensory analysis on meat. However, it may be hypothesized, following Cameron et al. (2000) who reported that pork flavour, flavour liking, and overall acceptability are positively correlated with the intramuscular concentration of linoleic, arachidonic and $\mathrm{C} 22: 4 \mathrm{n}-6$, that the increase of these fatty acids observed in our study may contribute to improve pork meat palatability and healthiness.

For PUFA of the n-3 series, dietary extruded linseed increased the proportion of linolenic acid $(P$ $<0.05)$ along with $\mathrm{C} 20: 3, \mathrm{C} 20: 5, \mathrm{C} 22: 5$, and $\mathrm{C} 22: 6(P<0.01)$. This increase in the proportion of $n-3$ fatty acids reflects the higher concentration of linolenic acid present in the extruded linseed diet that was fed. Our results are similar to those reported by Juárez et al. (2011) even though we fed a diet containing less extruded linseed. Huang et al. (2008) and He-Feng et al. (2009) also found that a greater duration of feeding linseed effectively increased the muscle PUFA content. Therefore, in our study it may be hypothesized that although we used a lower extruded linseed dietary supplementation, the long duration of the dietary treatment may have provided positive results in terms of PUFA intramuscular concentration. 
Table 6 Fatty acid composition (\% of total fatty acid methyl esters) of meat from the Longissimus dorsi muscle of Nero Lucano pigs

\begin{tabular}{|c|c|c|c|c|}
\hline & \multicolumn{2}{|c|}{ Diets } & \multirow{2}{*}{ SE } & \multirow{2}{*}{ p-value } \\
\hline & Control & Extruded linseed & & \\
\hline Total fatty acids (g/100 g muscle) & 1.62 & 2.07 & & \\
\hline C14:0 (myristic) & 1.71 & 0.90 & 0.282 & 0.074 \\
\hline C16:0 (palmitic) & 24.68 & 19.39 & 1.596 & 0.058 \\
\hline C18:0 (stearic) & 12.94 & 10.07 & 0.308 & $<0.001$ \\
\hline C20:0 (arachidic) & 0.31 & 0.25 & 0.043 & 0.332 \\
\hline Total SFA ${ }^{2}$ & 39.99 & 30.73 & 1.761 & 0.010 \\
\hline C16:1 c9 (n-7) (palmitoleic) & 2.81 & 2.16 & 0.182 & 0.047 \\
\hline C18:1 c9 (n-9) (oleic) & 40.22 & 36.42 & 1.491 & 0.121 \\
\hline Total MUFA ${ }^{3}$ & 46.82 & 44.02 & 1.420 & 0.213 \\
\hline C18:2 c9,c12 (n-6) (linoleic) & 9.14 & 14.47 & 0.854 & 0.005 \\
\hline C20:2 c11,c14 (n-6) (eicosadienoic) & 0.42 & 0.70 & 0.071 & 0.029 \\
\hline C20:4 c5,8,11,14 (n-6) (arachidonic) & 0.10 & 0.21 & 0.032 & 0.049 \\
\hline Total $n-6^{4}$ & 10.01 & 16.16 & 0.859 & 0.002 \\
\hline C18:3 c9,12,15 (n-3) (gamma-linolenic) & 0.51 & 0.97 & 0.065 & 0.003 \\
\hline C20:3 c11,14,17 (n-3) (eicosatrienoic) & 0.46 & 2.69 & 0.148 & $<0.001$ \\
\hline C20:5 c8,11,14,17 (n-3) (EPA) & 0.02 & 0.19 & 0.021 & 0.001 \\
\hline C22:5 c 4,7,10,13,16 (n-3) (DPA) & 0.06 & 0.51 & 0.054 & 0.001 \\
\hline C22:6 n-3 c7,10,13,16,19 (n-3) (DHA) & 0.01 & 0.20 & 0.025 & 0.002 \\
\hline Total $n-3^{5}$ & 1.07 & 4.56 & 0.141 & $<0.001$ \\
\hline Total PUFA ${ }^{6}$ & 11.94 & 21.57 & 0.976 & 0.004 \\
\hline PUFA/SFA & 0.29 & 0.70 & 0.033 & $<0.001$ \\
\hline$n-6 / n-3$ & 9.35 & 3.55 & 0.108 & $<0.001$ \\
\hline Atherogenic index & 0.62 & 0.44 & 0.035 & 0.013 \\
\hline Thrombogenic index & 1.53 & 1.17 & 0.035 & $<0.001$ \\
\hline
\end{tabular}

${ }^{2}$ SFA: saturated fatty acids (sum of C10:0 + C12:0 + C14:0 + C15:0 + C16:0 + C17:0 + C18:0 + C20:0)

${ }^{3}$ MUFA: monounsaturated fatty acids (sum of C16:1cis $-9+C 17: 1$ cis-10 + C18:1trans-11 + C18:1trans-9 + C18:1trans$10+$ C18:1cis-9)

${ }^{4} \mathrm{n}-6$ : omega 6 (sum of C18:2 c9,t11 + C18:2 c9,c12 + C18:2 t10,c12 + C18:3 c6,9,12 + C20:2 c11,14 + C20:3 c8,11,14 + C20:4 c5,8,11,14 +

C22:5 c4,7,10,13,16)

${ }^{5} \mathrm{n}-3$ : omega 3 (sum of $\mathrm{C} 18: 3 \mathrm{c} 9,12,15+\mathrm{C} 20: 3 \mathrm{c} 11,14,17+\mathrm{C} 20: 4 \mathrm{c5}, 8, \mathrm{t} 10, \mathrm{c} 14+\mathrm{C} 20: 5 \mathrm{c} 8,11,14,17+\mathrm{C} 22: 5 \mathrm{c}$ $4,7,10,13,16+C 22: 6$ n-3 c7,10,13,16,19)

${ }^{6}$ PUFA: polyunsaturated fatty acids (sum of $\left.n-6+n-3\right)$.

In this study, feeding extruded linseed produced a significant decrease $(P<0.01)$ of the PUFA/SFA and n-6/n-3 ratios, with benefits for human health (Department of Health, 1994; Simopolous, 2001). In particular, the PUFA/SFA ratio should be greater than 0.4 and in our study the linseed diet increased this value to from 0.3 to 0.7 . Furthermore, the $n-6 / n-3$ ratio of 3.55 is below the recommended value of $4-5$. Also other Authors found a decrease of the $n-6 / n-3$ ratio in pig meat following a $5 \%$ flaxseed dietary addition and reported values similar to our results in other pig breeds (Matthews et al., 2000; Juárez et al., 2011; De Tonnac et al., 2017).

Because of the higher content of PUFA and the lower content of C18:0, meat from extruded linseed fed pigs had lower $(P<0.01)$ atherogenicity and thrombogenicity indices. These are two important indicators related to human health since they indicate risks of increase of serum lipid and excess of platelet activity, respectively (Ulbricht \& Southgate, 1991). Okrouhlá et al. (2013) found a significant decrease of the 
thrombogenicity index in both barrows and gilts fed with linseed but did not report any dietary effect on the atherogenicity index.

\section{Conclusions}

A diet that includes 3\% extruded linseed may present a viable option for feeding Nero Lucano pigs with few contraindications. Additional research should be carried out in order to assess whether the increase of the percentage of dietary linseed supplementation may further improve performance and meat quality in the autochthonous Nero Lucano pig breed.

\section{Authors' Contributions}

ST conceived and designed the study. MAC helped in designing the study, carrying out statistical analysis and interpretation of the data, collaborated in performing the experimental work, laboratory analysis, preparation of the manuscript and wrote the paper. ST and FG collaborated in animal management, in the collection of the productive performance data and carried out meat analysis. MR and AL collaborated in the preparation of the manuscript. AMF was involved in the statistics and interpretation of the data and constructive revision of the manuscript and helped with writing the paper.

\section{Conflict of Interest Declaration}

The authors declare that they have no competing interests.

\section{References}

AOAC, 1995. Official methods of analysis (16th ed.). Association of Official Analytical Chemists, Inc., Arlington, Virginia, USA.

AOAC, 2004. Official methods of analysis (18th ed.). Association of Official Analytical Chemists, Inc., Arlington, Virginia, USA.

ASPA, 1991. Metodologie relative alla macellazione degli animali di interesse zootecnico e alla valutazione e dissezione della loro carcassa (Procedures for slaughter of livestock animals and evaluation and dissection of their carcasses). Scientific Association of Animal production, Università di Perugia, Perugia, Italy (in Italian).

ASPA, 1996. Metodiche per la determinazione delle caratteristiche qualitative della carne (Procedures for meat quality evaluation). Scientific Association of Animal Production, Università di Perugia, Perugia, Italy (in Italian).

Barahona, M., Olleta, J.L., Sańudo, C., Albertí, P., Panea, B., Pérez-Juan, M., Realini, C.E. \& Campo, M.M., 2016. Effects of whole linseed and rumen-protected conjugated linoleic acid enriched diets on beef quality. Animal 10, 709-717.

Bečková, R. \& Václavková, E., 2010. The effect of linseed diet on carcass value traits and fatty acid composition in muscle and fat tissue of fattening pigs. Czech J. Anim. Sci. 55, 313-320.

Bee, G., Jacot, S., Guex, G. \& Biolley, C., 2008. Effects of two supplementation levels of linseed combined with CLA or tallow on meat quality traits and fatty acid profile of adipose and different muscle tissues in slaughter pigs. Animal $2800-811$.

Bekhit A.E.-D.A., Carne, A., Ha, M. \& Franks, P., 2014. Physical interventions to manipulate texture and tenderness of fresh meat: a review. Int. J. Food Prop. 17, 433-453.

Bouton, P.E., Harris, P.V., Ratcliff, D. \& Roberts, D.W., 1978. Shear force measurements in cooked meat from sheep of various ages. J. Food Sci. 43, 1038-1039.

Cameron, N.D, Enser, M., Nute, G.R., Whittington, F.M., Penman, J.C., Fisken, A.M., Perry, J. \& Wood, J.D., 2000. Genotype with nutrition interaction on fatty acid composition of intramuscular fat and the relationship with flavour of pig meat. Meat Sci. 55, 187-195.

Choe, J.H., Choi, M.H., Rhee, M.S. \& Kim, B.C., 2016. Estimation of sensory pork loin tenderness using Warner-Bratzler Shear Force and Texture Profile Analysis measurements. Asian-Austral. J. Anim. Sci. 29, 1029-1036.

Christie, W.W., 1982. Lipid analysis-isolation, separation, identification and structural analysis of lipids. Pergamon, Oxford. pp. 270.

Colonna, M.A., Giannico, F., Coluccia, A., Di Bello, G., Vonghia, G. \& Caputi Jambrenghi, A., 2011. Dietary supplementation with extruded linseed and linseed oil in lamb feeding: Productive performances and meat quality traits. Progr. Nutr. 13, 111-124.

Corino, C., Musella, M. \& Mourot, J., 2008. Influence of extruded linseed on growth, carcass composition and meat quality of slaughtered pigs at one hundred and one hundred sixty kilograms of liveweight. J. Anim. Sci. 86 18501860.

D’Arrigo, M., Hoz, L., Lopez-Bote, C.J., Cambero, I., Pin, C., Rey, A.I. \& Ordóñez, J.A., 2002. Effect of dietary linseed oil and $\alpha$-tocopherol on selected properties of pig fat. Can. J. Anim. Sci. 82, 339-346.

Department of Health, 1994. Nutritional aspects of cardiovascular disease. Report on Health and Social Subjects, No. 46 HMSO, London, UK.

De Tonnac, A., Karim-Luisset, S. \& Mourot, J., 2017. Effect of different dietary linseed sources on fatty acid composition in pig tissues. Livest. Sci. 203, 124-131.

Directive 2010/63/EU. Legislation for the protection of animals used for scientific purposes (available at the website http://ec.europa.eu/environment/chemicals/lab_animals/legislation_en.htm).

Dur, M., 2019. trends in agri-food choices for health since the 1960s: the case of fatty acids. OCL $26,44$. 
Enser, M., Richardson, R.I., Wood, J.D., Gill, B.P. \& Sheard, P.R., 2000. Feeding linseed to increase the n-3 PUFA of pork: fatty acid composition of muscle, adipose tissue, liver and sausages. Meat Sci. 55, 201-212.

Facciolongo, A.M., Lestingi, A., Colonna, M.A., Nicastro, F., De Marzo, D. \& Toteda, F., 2018. Effect of diet lipid source (linseed vs. soybean) and gender on performance, meat quality and intramuscular fatty acid composition in fattening lambs. Small Rumin. Res. 159, 11-17.

Folch, J., Lees, M. \& Sloan- Stanley, G.H., 1957. A simple method for the isolation and purification of total lipides from animal tissues. J. Biol. Chem. 226, 497-509.

Franci, O., Bozzi, R., Pugliese, C., Acciaioli, A., Campodoni, G. \& Gandini, G., 2005. Performance of Cinta Senese pigs and their crosses with Large White - 1. Muscle and subcutaneous fat characteristics. Meat Sci. 69, 545-550.

Guillevic, M., Kouba, M. \& Mourot, J., 2009. Effect of a linseed diet or a sunflower diet on performances, fatty acid composition, lipogenic enzyme activities and stearoyl-CoA-desaturase activity in the pig. Liv. Sci. 124, 288-294.

Haak, L., De Smet, S., Fremaut, D., Van Walleghem, K. \& Raes, K., 2008. Fatty acid profile and oxidative stability of pork as influenced by duration and time of dietary linseed or fish oil supplementation. J. Anim. Sci. 86, 1418-1425.

He-Feng, L., Hong-Kui, W., Fei-Ruo, H., Zheng, Z., Si-Wen, J. \& Jian, P., 2009. The effect of linseed on intramuscular fat content and adipogenesis related genes in skeletal muscle of pigs. Lipids 44, 999-1010.

Hoffman, L.C., Muller, M., Cloete, S.W.P. \& Schmidt, D., 2003. Comparison of six crossbred lamb types: sensory, physical and nutritional meat quality characteristics. Meat Sci. 65, 1265-1274.

Huang, F.R., Zhan, Z.P., Luo, J., Liu, Z.X. \& Peng, J., 2008. Duration of dietary linseed feeding affects the intramuscular fat muscle mass and fatty acid composition in pig muscles. Livest. Sci. 118, 132-139.

INRA, 1989. L'alimentation des animaux monogastriques: porc, lapin, volailles. Institut National de la Recherche Agronomique. (INRA), Paris, France, ISBN: 2-7380-0139-4.

Juárez, M., Dugan, M.E.R., Aldai, N., Aalhus, J.L., Patience, J.F., Zijlstra, R.T. \& Beaulieu, A.D., 2010. Feeding coextruded flaxseed to pigs: effects of duration and feeding level on growth performance and backfat fatty acid composition of grower-finisher pigs. Meat Sci. 84, 578-584.

Juárez, M., Dugan, M.E.R., Aldai, N., Aalhus, J.L., Patience, J.F., Zijlstra, R.T. \& Beaulieu, A.D., 2011. Increasing omega-3 levels through dietary co-extruded flaxseed supplementation negatively affects pork palatability. Food Chem. 126, 1716-1723.

Kasprzyk, A., Tyra, M. \& Babicz, M., 2015. Fatty acid profile of pork from a local and a commercial breed. Arch. Anim. Breed. 58, 379-385.

Kouba, M., Enser, M., Whittington, F.M., Nute, G.R. \& Wood, J.D., 2003. Effect of a high-linolenic acid diet on lipogenic enzyme activities, fatty acid composition and meat quality in the growing pig. J. Anim. Sci. 81, 1967-1979.

Kouba, M. \& Mourot, J., 2011. A review of nutritional effects on fat composition of animal products with special emphasis on $n-3$ polyunsaturated fatty acids. Biochimie 93, 13-17.

Maiorano, G., Cavone, C., Paolone, K., Pilla, F., Gambacorta, M. \& Manchisi, A., 2007. Effects of slaughter weight and sex on carcass traits and meat quality of Casertana pigs reared outdoors. Ital. J. Anim. Sci. (Suppl. 1), 698-700.

Marsico, G., Tarricone, S., Karatosidi, D., Ragni, M., De Vito, N., Vicenti, A. \& Pinto F., 2011. Evolution of meat quality of black pig with the age of slaughter. Progr. Nutr. 13, 292-299.

Matthews, K.R., Homer, D.B., Thies, F. \& Calder, P.C., 2000. Effect of whole linseed (Linum usitatissimum) in the diet of finishing pigs on growth performance and on the quality and fatty acid composition of various tissues. Br. J. Nutr. 83, 637-643.

Micha, R., Michas, G. \& Mozaffarian, D., 2012. Unprocessed red and processed meats and risk of coronary artery disease and type 2 diabetes - An updated review of the evidence. Curr. Atherosclerosis Rep. 14, 515-524.

Nguyen, L.Q., Everts, H. \& Beynen, A.C., 2004. Influence of dietary linseed, fish and coconut oil on growth performance of growing finishing pigs kept on small holdings in central Vietnam. J. Anim. Phys. Anim. Nutr. 88, 204-210.

Okrouhlá, M., Stupka, R., Ćítek, J., Šprysl, M. \& Brzobohatý, L., 2013. Effect of dietary linseed supplementation on the performance, meat quality, and fatty acid profile of pigs. Czech. J. Anim. Sci. 58, 279-288.

Pugliese, C. \& Sirtori, F., 2012. Quality of meat and meat products produced from southern European pig breeds. Meat Sci. 90, 511-518.

Raes, K., De Smet, S. \& Demeyer, D., 2004. Effect of dietary fatty acids on incorporation of long chain polyunsaturated fatty acids and conjugated linoleic acid in lamb, beef and pork meat: a review. Anim. Feed Sci. Technol. 113, 199221.

Rotondi, P., Colonna, M.A., Marsico, G., Giannico, F., Ragni, M. \& Facciolongo, A.M., 2018. 2, Dietary supplementation with Oregano and Linseed in Garganica Suckling Kids: Effects on Growth Performances and Meat Quality. Pak. J. Zool. 50 (4), 1421-1433.

Simopoulos, A.P., 2001. N-3 fatty acids and human health: defining strategies for public policy. Lipids (Suppl.) 36, 583589.

Šicklep, M. \& Čandek-Potokar, M., 2007. Pork color measurement as affected by bloom time and measurement location. J. Muscle Foods 18, 78-87.

Thompson, J., 2002. Managing meat tenderness. Meat Sci. 62, 295-308.

Tarricone, S., Marsico, G. Melodia, L. Ragni, M., Colangelo, D., Karatosidi, D., Rasulo, A. \& Pinto, F., 2010. Meat quality of pigs, $F_{1}, F_{2}$, reared and wild wild boars. Progr. Nutr. 12, 261-271.

Tarricone, S., Colonna, M.A., Giannico, F., Facciolongo, A.M., Caputi Jambrenghi, A. \& Ragni, M., 2019. Effects of dietary extruded linseed (Linum usitatissimum L.) on performance and meat quality in Podolian young bulls. S. Afr. J. Anim. Sci. 49(4), 781-789.

Ulbricht, T.L. \& Southgate, D.A.T., 1991. Coronary heart disease: Seven dietary factors. The Lancet 338, 985-922. 
Vahmani, P., Mapiye, C., Pieto, N., Rolland, D.C., McAllister, T.A., Aalhus, J.L. \& Dugan, M.E.R., 2015. The scope for manipulating the polyunsaturated fatty acid content of beef: a review. J. Anim. Sci. Biotechnol. 6, 1-13.

Wood, J.D., Enser, M., Fisher, A.V., Nute, G.R., Richardson, R.I. \& Sheard, P.R., 1999. Manipulating meat quality and composition. Proc. Nutr. Soc. 58, 363-370.

Wood, J.D., Richardson, R.I., Nute, G.R., Fisher, A.V., Campo, M.M. \& Casapidou, E., 2003. Effects of fatty acids on meat quality: a review. Meat Sci. 66, 21-32.

Zhan, Z.P., Huang, F.R., Luo, J., Dai, J.J., Yan, X.H. \& Peng, J., 2009. Duration of feeding linseed diet influences expression of inflammation-related genes and growth performance of growing-finishing barrows. J. Anim. Sci. 87, 603-611. 